\title{
リードフレーム用銅合金におけるマイグレーション性の評価
}

\author{
両角 宏喜*, 加藤 凡典 ${ }^{* *}$, 上田 重朋***
}

\section{Evaluation of Copper Migration on Taped Lead Frames}

Hiroki MOROZUMI*, Kazunori KATO** and Shigetomo UEDA**

\begin{abstract}
The dendritic migration of copper on taped lead frames is reproduced experimentally by dipping paird lead samples in pure water $\left(0.8 \mathrm{M} \Omega, 20 \pm 3^{\circ} \mathrm{C}\right)$ and subjecting them to a $\mathrm{DC}$ current of about $100 \mu \mathrm{A}$.

We found several effects of alloying elements and heat treatments for samples on migration. This migration model mechanism was suggested by investigating the microscopic structure of migration dendrites and analysing other supposable factors.
\end{abstract}

Key Words : Migration, Copper, Lead Frame, Dendritic Growth

\section{1. 緒 量}

電子機器の小型化・高性能化に伴い, 使用される部品 の高密度化（実装密度の増大）手進展している。

これは，主要部品であるIC，LSIなどの半導体にも同 様の傾向をむたらし，高集積度化は年々增加の傾向をた どってその構成部品であるリードフレームにあ種々の変 化を与えている。また，機器の高い特性を維持するうえ で信頼性は重要な問題であるが，それを取り巻く環境も 变化してきており, 益々複雑多岐にわたっている。

現在, 半導体の信頼性試験として, 熱的環境, 機械的 環境及び実装環境より各試験法が規定されている。とく に，半導体パッケージングの 8 割以上を占めている樹脂 封止を施される製品に対しては，樹脂特有の吸湿性など から耐湿性試験が行われている。近年，銅系リードフレー ムを用いたプラスチックパッケージの半導体に対してバ イアス印加でのPCT(Pressure Cooker Test)による 高温高湿度信頼性試験中に，そのリード間にマイグレー ションによりデンドライトが生成し短絡に至るケースが 報告されている（図1）。これは,リードフレームにテー ピング*1を行って樹脂封止した場合に起こりやすい現象 であり，テープ上に四湿水分が溜まりリードが水中に浸 せきされたような状態になるためだと考えられている。 従来, 電子部品用金属材料のマイグレーションに関して

* 早稆田大学大学院（テ169 東京都新宿区大久保 3-4-1）

[現 : 東㜣 ]

Graduate School, Waseda Univ. (4-1, Ookubo 3-chome, Shinjuku-ku, Tokyo 169) (Present : TONEN Co.)

**大日本印刷(像（广356 埼玉県上福岡市福岡 2-2-1)

Dai Nippon Printing Co. (2-1, Fukuoka 2-chome,

Kamifukuoka-shi, Saitama 356)

**** 早稻田大学理工学部 ( 169 東京都新宿区西早稲田 2-8-26) [各務記念材料技術研究所]

School Sci. \& Eng., Waseda Univ. (8-26, Nishiwaseda 2chome, Shinjuku-ku, Tokyo 169)

[Kagami Memorial Inst. for Materials Sci. \& Tech.]
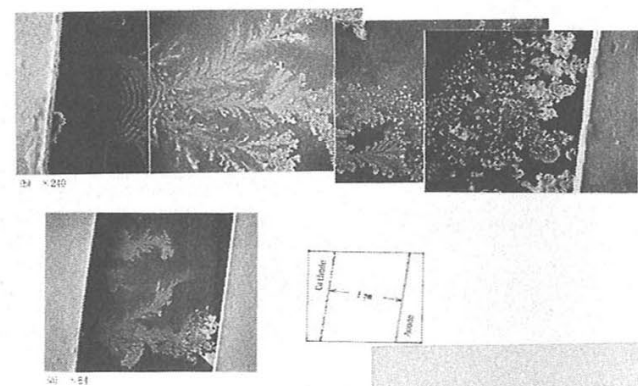

Fig. 1 Secondary electron image of dendritic growth in migration.

はAgによるるのが知られていたがリ 3)，近年，実用環 境とともに発生個所も変化してきており，銅系リードフ レームにおけるマイグレーションによる信頼性障害はそ の機器の信頼性をも損なってしまう重要な問題である。

そこで本研究では, 各種リードフレーム用銅合金を用 いて定電流法によりマイグレーション性を評価し，マイ グレーションによる成長物, 及びその発生因子，モデル 機構を各種分析装置を用いて考察した。

\section{2. 方 法}

供試材として各種リードフレーム用銅合金より選択し た10試料を表 1 に示す。各供試材を安定な実験試料とす るために前処理を施した。前処理法としては，アセトン による超音波脱脂したのち陰極法により電解脱脂, そし て塩酸 (10wt\%) での酸洗を行った。また，この際試 料表面にポリイミドフィルムによりマスキングを施し, $\phi 15 \mathrm{~mm}$ の均一な実験試料面を作製した。図 2 に実験装

*1 100pinを越える多ピンリードフレームや銅材ベースのリー ドフレームにおいては, アセンブリ工程中での变形防止を 目的とし， $50 \mu \mathrm{m}$ の゚リイミドフィルムに接着剂を塗布した テープを幅1.5〜2.0 mmに切断したものでリードを固定する 方法が1984年頃から行われるようになっている。 
Table 1 Sample condition.

\begin{tabular}{c|l|l|r}
\hline $\begin{array}{c}\text { alloy } \\
\text { code }\end{array}$ & \multicolumn{1}{|c|}{ name } & \multicolumn{1}{|c|}{ chemical composition, \% } & \%IACS \\
\hline A & OFHC & $>99.96 \mathrm{Cu}$ & $>96$ \\
B & EFTEC 3 & Cu-0.15 Sn-P & 90 \\
C & EFTEC 64T & Cu-0.3Cr-0.25Sn-0.2Zn & 75 \\
D & CDA 19400 & Cu-2.16Fe-0.13Zn-P & 65 \\
E & CDA 70250 & Cu-2.53Ni-0.41Si-0.1Mg & 40 \\
F & C 2600 & Cu-30Zn & 25 \\
G & EFTEC 75X & Cu- 3 Sn- 3 Ni-0.65Si-0.5Zn & 25 \\
H & CDA 51100 & Cu- 4 Sn-P & 20 \\
I & CDA 72400 & Cu-11.8Ni-1.97Al-0.31Mn-0.2Mg & 15 \\
J & CDA 52100 & Cu-8 Sn-P & 12 \\
\hline
\end{tabular}
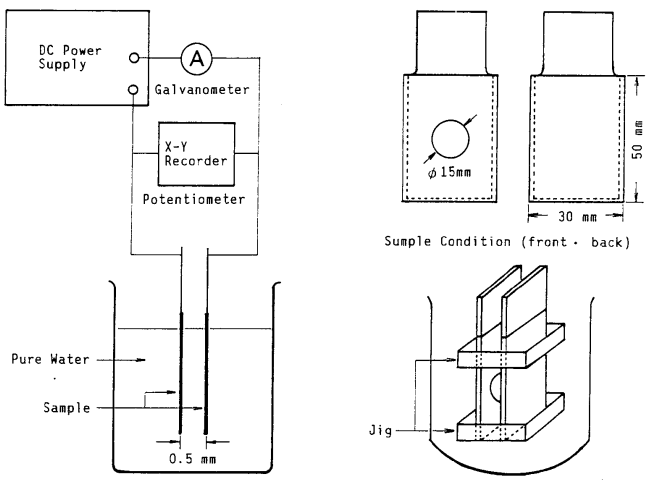

Sunple Condition (front. back

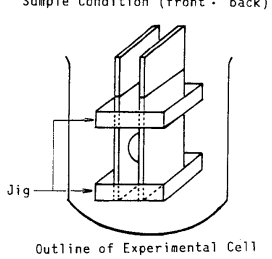

Fig. 2 Experimental apparatus.

置の概略図とマスキング後の試料を示す。

マイグレーション性の評価にあたり，実験装置として 定電流法を用いた。これは，前処理を行った一対の同一 合金の試料をマイグレーション現象の加速度的条件とし て，治具を使って面一面の状態で固定したうえで純水中 に浸せきし，直流定電流法によって試料間の電圧の経時 変化を, 回路間の電圧の経時変化として記録計に測定す るあのである。そしてこの時, 一定以上の電圧降下があっ たあのを短絡としてマイグレーション性の指標とした。

なお，実験条件としては試料面間距離は $0.5 \mathrm{~mm}$ ，定

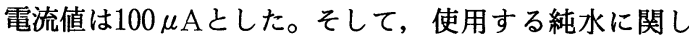
ては純水抵抗值が測定直前で $0.8 \sim 0.9 \mathrm{M} \Omega\left(20 \pm 3{ }^{\circ} \mathrm{C}\right)$ のあのを用意した。

\section{1 銅のマイグレーション性の確認}

本実験に入る前に，この実験条件下での電子部品用金 属材料のマイグレーション性を，実験試料と同一形状の 42合金上に以下のめっき皮膜 $(5 \mu \mathrm{m})$ を作製させるこ とにより確認した。

めっき皮膜としては, 金, 銀, 銅, パラジゥム, ニッ ケル，はんだの計 6 種を用いた。

\section{2 熱処理によるマイグレーション性への影壦}

リードフレームが半導体の構成部品として夷装される 工程では，様々な形で熱が加えられている。そこで，予 想される加熱過程を熱処理によって再現し，その試料を
用いてマイグレーション性の評価を行った。

熱処理条件としては,

1) $\left.150^{\circ} \mathrm{C} \times 5 \mathrm{~min}, 2\right) 200^{\circ} \mathrm{C} \times 5 \mathrm{~min}$,

3) $\left.150^{\circ} \mathrm{C} \times 2 \mathrm{~h}, 4\right) 150^{\circ} \mathrm{C} \times 2 \mathrm{~h}+200^{\circ} \mathrm{C} \times 5 \mathrm{~min}$

の 4 段階で行った。

なお，その処理面の表面分析及び梁さ方向分析をAES を用いて行った。

\section{3 成長物の観察, 分析}

ポリイミドフィルム上に作製した成長物を，SEM及 びTEMを用いて観察，分析した。

\section{4 成長物の発生因子, 発生機構の考察}

各試料におけるマイグレーション性の差異との関連付 けを，X線回折による試料表面の配向指数の算出及び純 水に対する自然電極電位の測定により試みた。また，銅 におけるマイグレーションのモデル機構を, 解明されて いる銀によるものと比較検討しながら本実験の結果とと あに考察した。

\section{3. 結果および考察}

\section{1 銅のマイグレーション性の確認}

図 3 に銅のマイグレーション性を示す。

グラフ化に際しては，銅の短絡時間を基本值にして各 金属皮膜の短絡時間に対する銅の短絡時間の相対度数を 算出するという方法で行った。

結果より，本実験条件における電子部品用金属材料で は $\mathrm{Cu}>\mathrm{Sn}-\mathrm{Pb}>\mathrm{Ag} \gg \mathrm{Ni}, \mathrm{Au}, \mathrm{Pd}$ る順位のマイ グレーション性が確認された。

表 2 には, 各皮膜の測定時における平均電極間電圧を 示す。

定性的ではあるが，マイグレーション過程を想定した 本条件において銅のマイグレーション性がかなり高いこ とが確認された。

従来より銀および他の電子部品用金属材料について, マイグレーションに関する研究が行われてきているが, 実用環境の変化に伴いマイグレーションが発生する環境 因子あ変化してきており，リードフレームにおける特殊

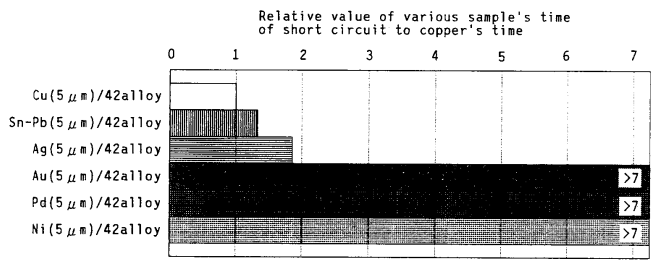

Fig. 3 Migration sensitivity in plating samples

Table 2 Average potential difference.

\begin{tabular}{c|c|c|c|c|c|c}
\hline & $\mathrm{Cu}$ & $\mathrm{Sn}-\mathrm{Pb}$ & $\mathrm{Ag}$ & $\mathrm{Ni}$ & $\mathrm{Au}$ & $\mathrm{Pd}$ \\
\hline electric potential, V & 1.647 & $4.0 \pm 2$ & 1.743 & 2.500 & 2.500 & 1.547 \\
\hline
\end{tabular}




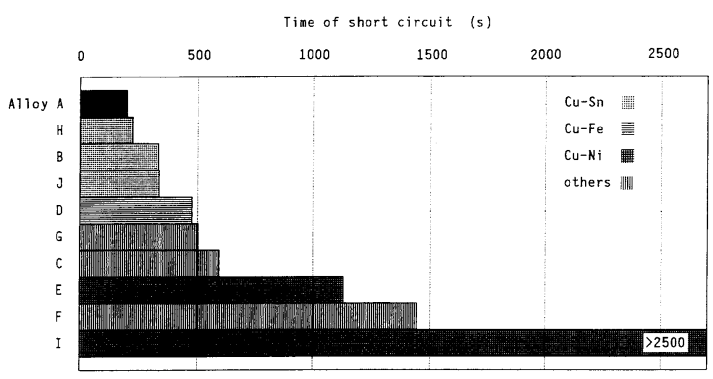

Fig. 4 Migration sensitivity in samples of different alloying element.

な状況下ではあるが，銅の問題点が明らかになった。

\section{2 供試材の組成とマイグレーション性の関係}

10試料の各供試材の短絡時間を図 4 に示す。同時に, 合金系をグラフパターンにより区分けしてみた。

まず無酸素銅（alloy A）が最も高いマイグレーショ ン性を示し，以下何らかの強化元素を含有している他の 合金は，少なからず無酸素銅より短絡時間を要しており， マイグレーション性が低くなっていることが分かった。

そしてグラフパターンからCu-Sn系とCu-Ni 系に大 きなマイグレーション性の差異が確認され，

純銅系 $>\mathrm{Cu}-\mathrm{Sn}>(\mathrm{Cu}-\mathrm{Fe})>\mathrm{Cu}-\mathrm{Ni}$

なる合金系の順位が得られた。

各合金系においても，添加元素の組成量が増加すると 短絡時間は長くなる傾向にある。

また, SnとNi については全般的な傾向は得ることが できたが, 組成比はかなり複雑に変化しており詳細にわ たっって述べることは難しい。

\section{3 熱処理によるマイグレーション性への影翼}

無酸素銅（alloy A）に対して4 段階の熱処理を施し た結果を図 5 (a) に示す。

熱処理条件が厳しくなるにつれて短絡時間がのびてお り，マイグレーション性の低化については，熱処理によ る酸化膜が影響を及ぼしていたことが推測される。

また同様の熱処理を alloy A, C, D, E, Gの計 5 試料 に対して $200^{\circ} \mathrm{C} \times 5 \mathrm{~min}$ のを行い, 熱処理前の短絡時 間と比較した結果を図 5 (b) に示す。いずれの試料も図 5 (a) の結果と同様に, 酸化膜の影響により短絡時間が のびていることが分かるが，その熱処理前後の比較から 大きく分けて 2 つの傾向が得られた。それは, alloy A, $\mathrm{G}, \mathrm{C}$ の処理後の短絡時間が処理前の 2 倍強を示したも のと, alloy D, Eのそれほどの変化を示さなかったも のである。

各試料とあ化学組成が異なっており，この結果から論 述することは難しく, 分析手段としてAESによる表面 及び深さ方向分析を行った。図 6 には，深さ方向分析の 結果として, O-KLL/Cu-LMMオージェピーク強度比 の推移を示す。

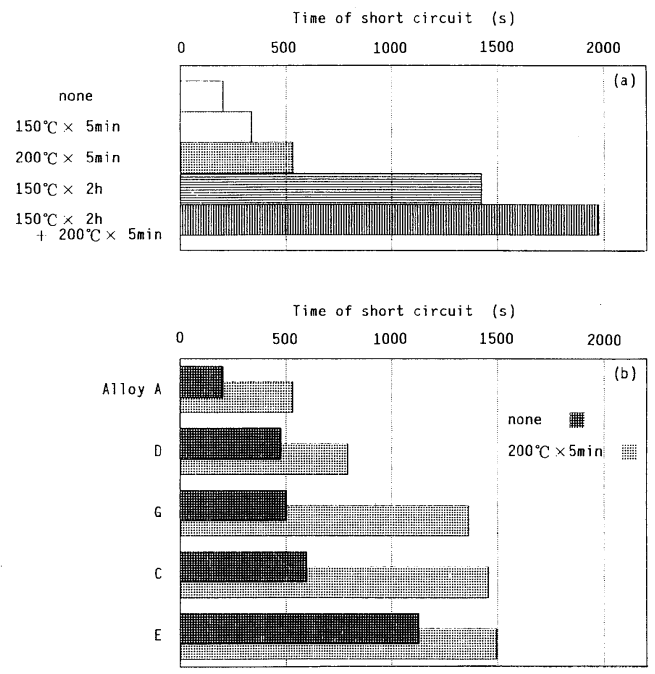

Fig. 5 Effect of heat treatments for migration sensitivity.

(a) Effect of heat treatments in alloy $\mathrm{A}$.

(b) Effect of heat treatments in five samples of different alloying element.

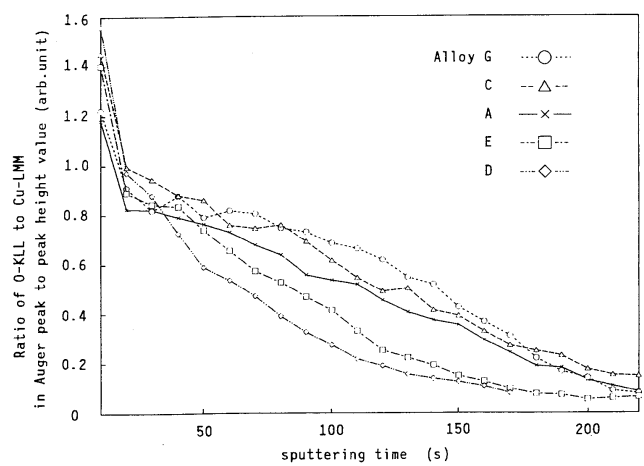

Fig. 6 Change of ratio of O-KLL to Cu-LMM in auger peak to peak height value from annealed samples at $200^{\circ} \mathrm{C}$ for $5 \mathrm{~min}$.

傾向として，熱処理前後の短絡時間の差が大きい試料 は強度比の変化勾配が他と比較して緩やかであり, 差の 少ない試料との軌跡がはっきり異なっていることが, 特 に150秒付近で確認できる。

このような傾向の差が得られた原因として考えられる 1 つのケースを, alloy Eと alloy Gの比較で述べる。

組成的には両者とあ Ni 添加による強化合金であるが, 更に alloy GにはNi と同量wt\%のSnが添加されてお りやや異なった組織を有していたものと思われる。

図 7 及び図 8 に，熱処理を施した各試料のスパッタリ ング前後のオージェスペクトルを示す。Ni のピークは Cuのピークと重なってしまうためにはっきりと同定で きないが, alloy Gのスパッタリング後のスペクトル中 にSnのピークを確認することができる。また，図 9 に 
示した深さ方向プロファイル中にも, alloy Gの試料に は, $\mathrm{Sn}$ 挙動が確認されており $\mathrm{Sn}_{\mathrm{x}} \mathrm{O}$ 準生成されていた ことあ考えられる。従って, 両者の熱処理による酸化膜 の構造が異なっていたことが考察でき，短絡時間に違っ た傾向をあたらしたものと考えられる。

そして，図6における勾配の違いは，この点が影響を 及ぼしていたと思われる。

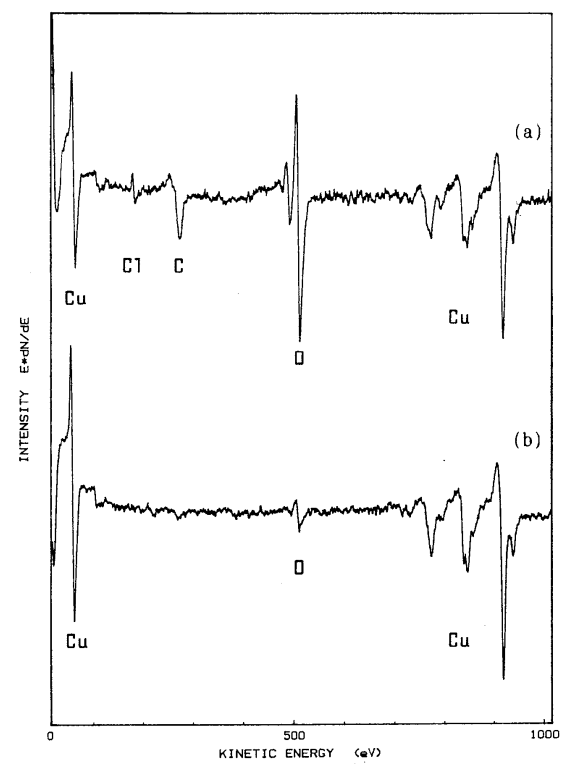

Fig. 7 Change of auger spectrum from alloy $E$ annealed at $200^{\circ} \mathrm{C}$ for $5 \mathrm{~min}$ with sputtering time.

(a) Before sputtering. (b) Sputtering time $=220 \mathrm{~s}$.

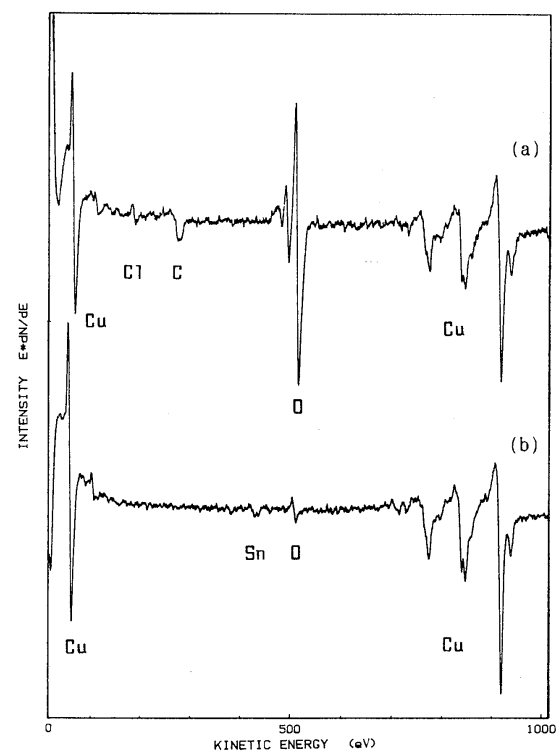

Fig. 8 Change of auger spectrum from alloy $G$ annealed at $200^{\circ} \mathrm{C}$ for $5 \mathrm{~min}$ with sputtering time.

(a) Before sputtering. (b) Sputtering time $=220 \mathrm{~s}$.

\section{4 成長物の観察, 分析}

本実験で再現したポリイミドフィルム上の成長物の二 次電子像を図 1 に示す。

全体として樹枝状を呈しており，さらに微視的な観察 をTEMにより行った結果を図10と図11に示す。

図10および図11は，とあに alloy Gからの成長物の 明視野像之制限視野電子回折像である。

このように，同じ成長物内にかなりデンドリックな部 分と, そうでない微結晶の集合体のような部分があるこ とが他の試料の成長物からあ確認されている。

また図11の回折像のリングから解析した結果, $\mathrm{Cu}$ と $\mathrm{Cu}_{2} \mathrm{O}$ が同定された。このほか無酸素銅からの成長物を 含めた一連の観察・分析により，素材成分としてNi や Snなどの添加元素が存在しているにも関わらず，成長 物の主構成元素はCuであることが推察される。

図10の電子回折像の指数付けの結果, このデンドライ トの幹の成長方向が〈111〉であることが分かる。

これは, 面心立方構造 (fcc) をとる $\mathrm{Cu}$ 最密面の方 向であり理論的にも成立する。

また，このときの晶帯軸は〈 $11 \overline{2}\rangle$ である。

この成長物の形態形成に関して, Znの電析過程にお いて大変興味深い研究が報告されている ${ }^{4)}$,5)。

樹枝状の成長形態は，そのイオンの濃度と印加電圧の
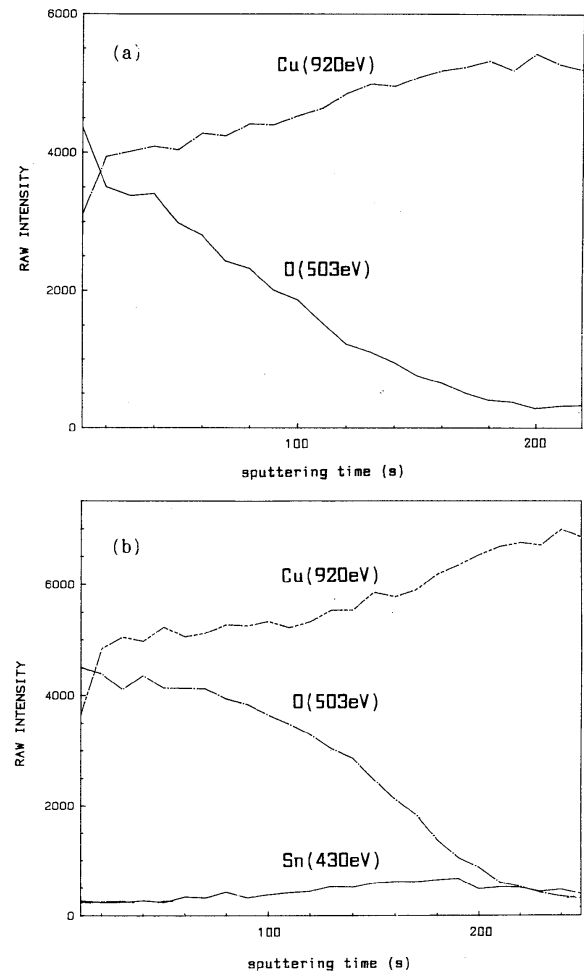

Fig. 9 AES depth profile from annealed samples at $200{ }^{\circ} \mathrm{C}$ for $5 \mathrm{~min}$.

(a) Alloy E. (b) Alloy G. 


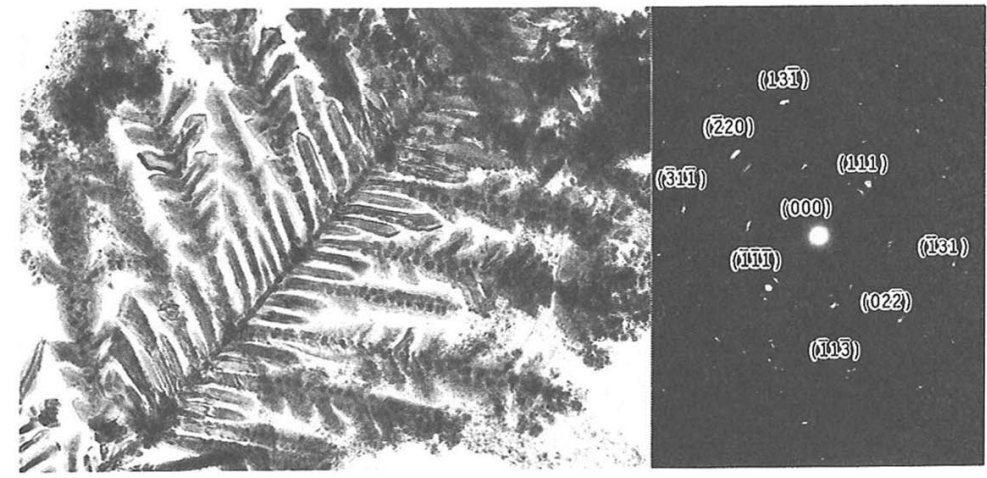

(a)

$1 \mu \mathrm{m}$

(b)

Fig. 10 Transmission electron micrograph of dendritic growth (dendritic part) from alloy $G$ and electron diffraction pattern.

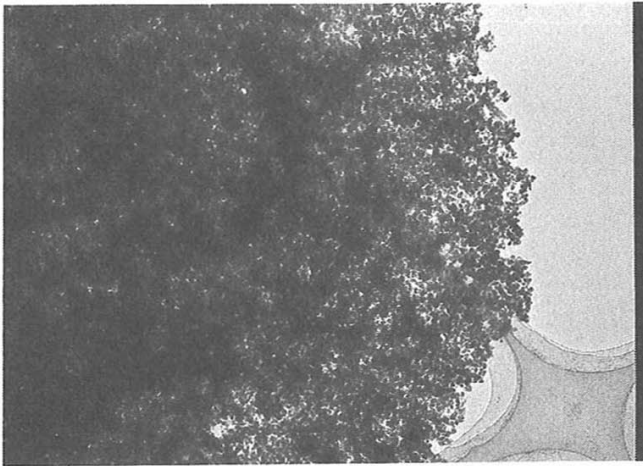

(a)
$1 \mu \mathrm{m}$

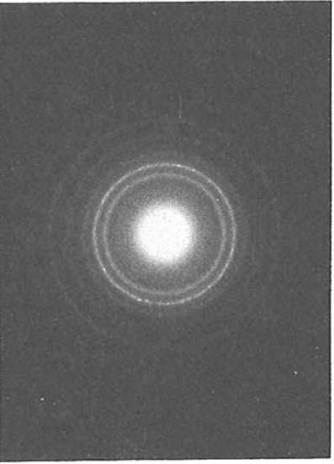

(b)

Fig. 11 Transmission electron micrograph of dendritic growth (no dendritic part) from alloy $G$ and electron diffraction pattern.

大きさによって異なった外形を呈するというすのであり， 本結果で得られた形態の解析に重要な示唆を与えてくれ ている。

つまり，巨視的には樹枝状を呈しているマイグレーショ ンによる成長物む，局所的な雾囲気での成長を経て全体 が形成されているということである。

\section{5 成長物の発生因子, 発生機構の考宲}

マイグレーションがいわゆる電解現象であるというこ とから，簡易法としてX線回折によりwillsonなどの式 を用いて配向指数を算出し，試料となる各供試材表面の 配向性をとらえ，それがマイグレーション過程における 溶解速度の変化と成長物の初期成長に際し, 各供武材の 短絡時間に影響を及ぼしているか否か関連付けを試みた。

しかしながら，大部分の試料が圧延によると思われる 加工集合組織として〈220〉方向に配向していることが確 認されただけで, マイグレーション性との関係は認めら れなかった。

そのため, 傾向として試料表面の微細な構造的因子は マイグレーション性に直接は影響を及ばしておらず，そ
れよりす電解現象そのあのが大きく作用していることが 考えられる。

そこでさらに，試料の純水に対する自然電極電位の測 定あ試みてみたが，全体的に数十 $\mathrm{mV}$ 程度のばらつきを 示したのみにとどまり，マイグレーション性との明らか な関係は得ることはできなかった。

マイグレーション過程が, その電極の溶解による電析 であることから、このような電気化学的な考察は重要で ある。しかしながら，条件が特殊であるために分析が難 しく, 今回とは異なった角度からのアプローチが必要で あると思われる。

以上これまでの各結果ととあに，既に解明されてい る銀のマイグレーションにおけるモデル機構より，銅の マイグレーション現象のモデル機構を考察する。

まず重要なことは,この現象が水分を媒体とした電解 現象であり,カソードとなる電極上に電析した後アノー ドに向かって成長し短絡に至っていることである。

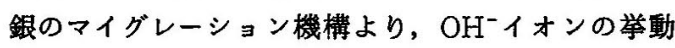
が重要であることが分かっている。これにより，中間生 
成物として不安定な水酸化物コロイドができ移行現象に

関与していると思われる。

予想される銅のマイグレーション機構としては，以下 のように考えられる。まず電流 (電圧) 㧅加直後加ら力 ソードとアノードの両極で以下の反応が生じる。

$$
\begin{aligned}
& (\text { カソード) } \\
& \mathrm{H}_{2} \mathrm{O}+1 / 2 \mathrm{O}_{2}+2 \mathrm{e}^{-} \rightarrow 2 \mathrm{OH}^{-} \\
& \mathrm{H}_{2} \mathrm{O}+\mathrm{e}^{-} \rightarrow 1 / 2 \mathrm{H}_{2}+\mathrm{OH}^{-} \\
& (\text {アノ-ド) } \\
& \mathrm{H}_{2} \mathrm{O} \rightarrow 1 / 2 \mathrm{O}_{2}+2 \mathrm{H}^{+} \\
& \mathrm{Cu} \rightarrow \mathrm{Cu}^{2+}+2 \mathrm{e}^{-} \\
& \mathrm{M} \rightarrow \mathrm{M}^{n+}+n \mathrm{e}^{-}
\end{aligned}
$$

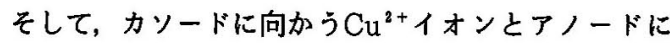
移動するOH-イオンが結合して，不安定な水酸化物コ ロイドを生成する。

$$
\mathrm{Cu}^{2+}+2 \mathrm{OH}^{-} \rightarrow \mathrm{Cu}(\mathrm{OH})_{2}
$$

さらに, カソード上では

$$
2 \mathrm{Cu}(\mathrm{OH})_{2}+2 \mathrm{e}^{-} \rightarrow \mathrm{Cu}_{2} \mathrm{O}+\mathrm{H}_{2} \mathrm{O}
$$

なる反応を生じて全体的には

$$
2 \mathrm{Cu}^{2+}+4 \mathrm{OH}^{-}=2 \mathrm{Cu}(\mathrm{OH})_{2} \rightarrow \mathrm{Cu}_{2} \mathrm{O}+\mathrm{H}_{2} \mathrm{O}
$$

の過程を繰り返してカソード上で放電しCuに還元さ れ、アノードに向かって成長すると推測される。

また，一旦成長の核ができると，電場の集中により加 速度的に成長し短絡に至っており，図12には純水中にお けるモデル実験での模様を示す。

そして，以上の推察よりこの過程の律速段階として考 えられるのが, 中間生成物の安定性である。これが不溶 性であったり上式の反応が起こり難かったりすると，そ の部分が律速となっていると考えられる。

従って，銅合金中の添加元素によるマイグレーション 性への影響としては，電解現象に際しての添加元素の優 先溶解, 添加元素による酸化膜挙動の変化, そしてモデ ル機構における中間生成物の安定性などが考えられる。

\section{4. 結言}

定電流法によりマイグレーション性を評価し，マイグ レーションによる成長物を観察・分析し，その発生因子 およぴモデル機構を各種分析装置により考察した結果, まず本実験条件下での銅のマイグレーション性が, 電子 部品用金属材料において極めて高いことが確認された。

そして，化学組成の異なる各種リードフレーム用銅合 金では, 合金系によりそのマイグレーション性が異なっ ていることが確認され，さらに熱処理によって生成され る試料表面の酸化膜の挙動によって, マイグレーション 性が低下することも分かった。

また，水分を媒体とするこのマイグレーションによる 成長物の発生過程が, 電場をドライビングフォースとし ており，一旦成長が始まると加速度的に成長し短絡に至

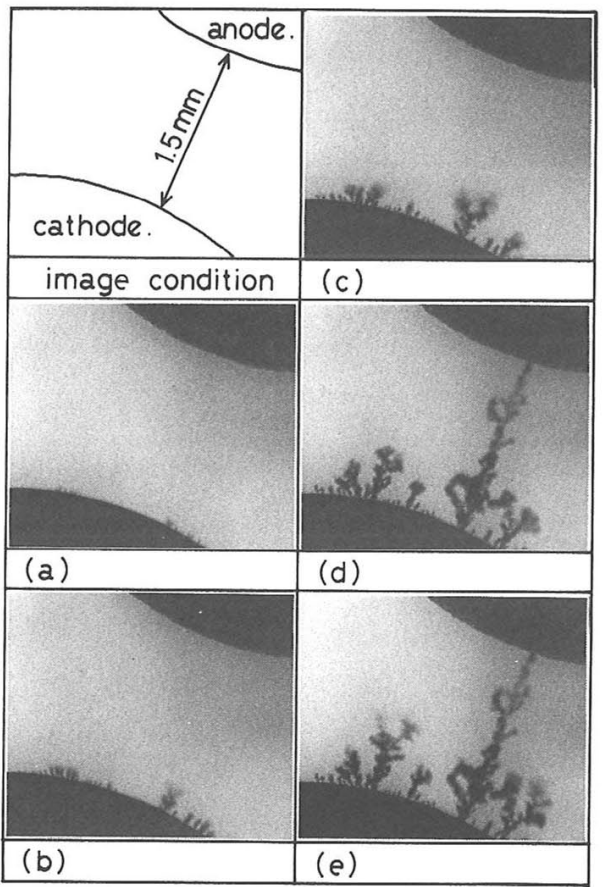

Fig. 12 Continuous photograph of dendritic growth in migration model. ( (a) (c) gradual, (c) (d) rapid)

ることが確認された。この樹枝状を呈する全体像の形態 形成に関しては，その成長物の主構成元素がCuであり， 局所的な雾囲気での成長の繰り返しによる集合体である あのと考えられる。

銅におけるマイグレーションのモデル機構としては, 銀と同様に水酸化物コロイドの役割が重要であると思わ れ，以下の全体反応によりカソード付近で放電し銅に還 元されていると考えられる。

$$
2 \mathrm{Cu}^{3+}+4 \mathrm{OH}^{-}=2 \mathrm{Cu}(\mathrm{OH})_{2} \rightarrow \mathrm{Cu}_{2} \mathrm{O}+\mathrm{H}_{2} \mathrm{O}
$$

半導体の高集積化に伴い, 実環境での信頼性障害は複 雑多岐にわたりその原因究明も困難になっている。一面 だけからでなく多方面からの視点による総合的な考察が 益々必要となってくるであろう。

本研究がその 1 つなれば幸いである。

(1991-5-7 受理)

\section{文献}

1) G. T. Kohman, H. W. Hermance and G. H. Downs ; The Bell System Tech. J, 34 (6), 1115 (1955)

2) 志賀章二, 柴田宣行, 谷川 徹 ; 古河電工時報, 75,37 (1985)

3) 村田安裕, 岩田洋子, 沼倉 弘, 長谷川知治; 電子通信学 会技術研究報告, R-85-18，31（1985）

4) Y. Sawada, A. Dougherty, J. P. Gollub ; Physical Review Letters, 56, 1260 (1986)

5) D. Grier, E. Ben-Jacob, Roy Clarke, L. M. Sander ; Physical Review Letters, 56, 1264 (1986) 